\title{
The influence of different metal-chelate conjugates of pentixafor on the CXCR4 affinity
}

\author{
Andreas Poschenrieder ${ }^{1 *}$, Margret Schottelius ${ }^{1}$, Markus Schwaiger ${ }^{2}$, Horst Kessler $^{3}$ and Hans-Jürgen Wester ${ }^{1}$
}

\begin{abstract}
Background: The overexpression of the chemokine receptor 4 (CXCR4) in different epithelial, mesenchymal, and hematopoietic cancers makes CXCR4 an attractive diagnostic and therapeutic target. However, targeting the CXCR4 receptor with small cyclic pentapeptide-based radiopharmaceuticals remains challenging because minor structural modifications within the ligand-linker-chelate structure often significantly affect the receptor affinity. Based on the excellent in vivo properties of CXCR4-directed pentapeptide $\left[{ }^{68} \mathrm{Ga}\right]$ pentixafor (Cyclo(-D-Tyr-N-Me-D-Orn(AMB-DOTA)L-Arg-L-2-Nal-Gly-)), this study aims to broaden the spectrum of applicable (radio)metal-labeled pentixafor analogs.

Methods: Cyclic pentapeptides, based on the pentixafor scaffold, were synthesized by a combined solid- and solutionphase peptide synthesis. The CXCR4 receptor affinities of the cold reference compounds were determined in competitive binding assays using CXCR4-expressing Jurkat T - cell leukemia cells and [ $\left.{ }^{125} \mid\right]$ FC131 as the radioligand.

Results: Metalated pentixafor derivatives with cyclic and acyclic chelators were synthesized by solid-phase peptide synthesis and evaluated in vitro. The resulting CXCR4 affinities $\left(I_{50}\right)$ were highly dependent on the chelator and metal used. Two pentapeptides, Ga-NOTA and Bi-DOTA conjugates, offer an improved affinity compared to $\left.{ }^{68} \mathrm{Ga}\right]$ pentixafor.

Conclusions: Based on the pentapeptide $\left[{ }^{68} \mathrm{Ga}\right]$ pentixafor, a broad range of metal-labeled analogs were investigated. The affinities of the new compounds were found to be strongly dependent on both the chelator and the metal used. Bi-labeled pentixafor showed high receptor affinity and seems to be a promising ligand for further preclinical evaluation and future a-emitter-based endoradiotherapy.
\end{abstract}

Keywords: GPCR, CXCR4, [ $\left.{ }^{68} \mathrm{Ga}\right]$ pentixafor, Pentapeptide, DOTA, Chelator, Radiopharmaceutical, Tracer, Cancer

\section{Background}

The chemokine receptor 4 (CXCR4) and its sole known natural ligand stromal cell derived factor-1 (SDF-1, CXCL12) are physiologically involved in leukocyte recruitment, homing, and retention of hematopoietic stem and progenitor cells $[1,2]$. CXCR4 also holds a substantial role in various pathological conditions and represents a highly attractive therapeutic target. Overexpression of CXCR4 has been linked to cancer proliferation, cell migration, and tissue-specific homing of cancer cells as well as resistance to conventional and targeted therapies [3-5].

\footnotetext{
* Correspondence: a.poschenrieder@tum.de

${ }^{1}$ Pharmaceutical Radiochemistry, Technical University Munich,

Walther-Meißner-Str.3, 85748 Garching, Germany

Full list of author information is available at the end of the article
}

After the identification of CXCR4 as a co-receptor for the entry of the HIV virus [6], great efforts have been made towards the development of CXCR4 antagonists. Recently, our group has developed $\left[{ }^{68} \mathrm{Ga}\right]$ pentixafor (cyclo(-D-Tyr-N$M e$-D-Orn(aminomethylbenzoyl (AMB)-DOTA)-L-Arg-L2-Nal-Gly-), $\left[{ }^{68} \mathrm{Ga}\right] \mathbf{1}$, Fig. 1), a cyclic pentapeptide with $5 \mathrm{nM}$ affinity and high selectivity towards hCXCR4 [7, 8]. $\left[{ }^{68} \mathrm{Ga}\right]$ pentixafor exhibits high uptake and long retention in CXCR4-expressing tissues $(6.16 \% \pm 1.16 \% \mathrm{ID} / \mathrm{g}, 1 \mathrm{~h}$ post-injection (p.i.) and $4.63 \% \pm 1.54 \%, 2$ h p.i. in $\mathrm{OH} 1$ human small cell lung cancer tumor-bearing mice) and is rapidly cleared from non-target tissue $(1.08 \% \pm 0.27 \%$ in the blood, $1 \mathrm{~h}$ p.i.) and renally excreted [7]; the corresponding tumor-to-blood and tumor-to-muscle ratios 


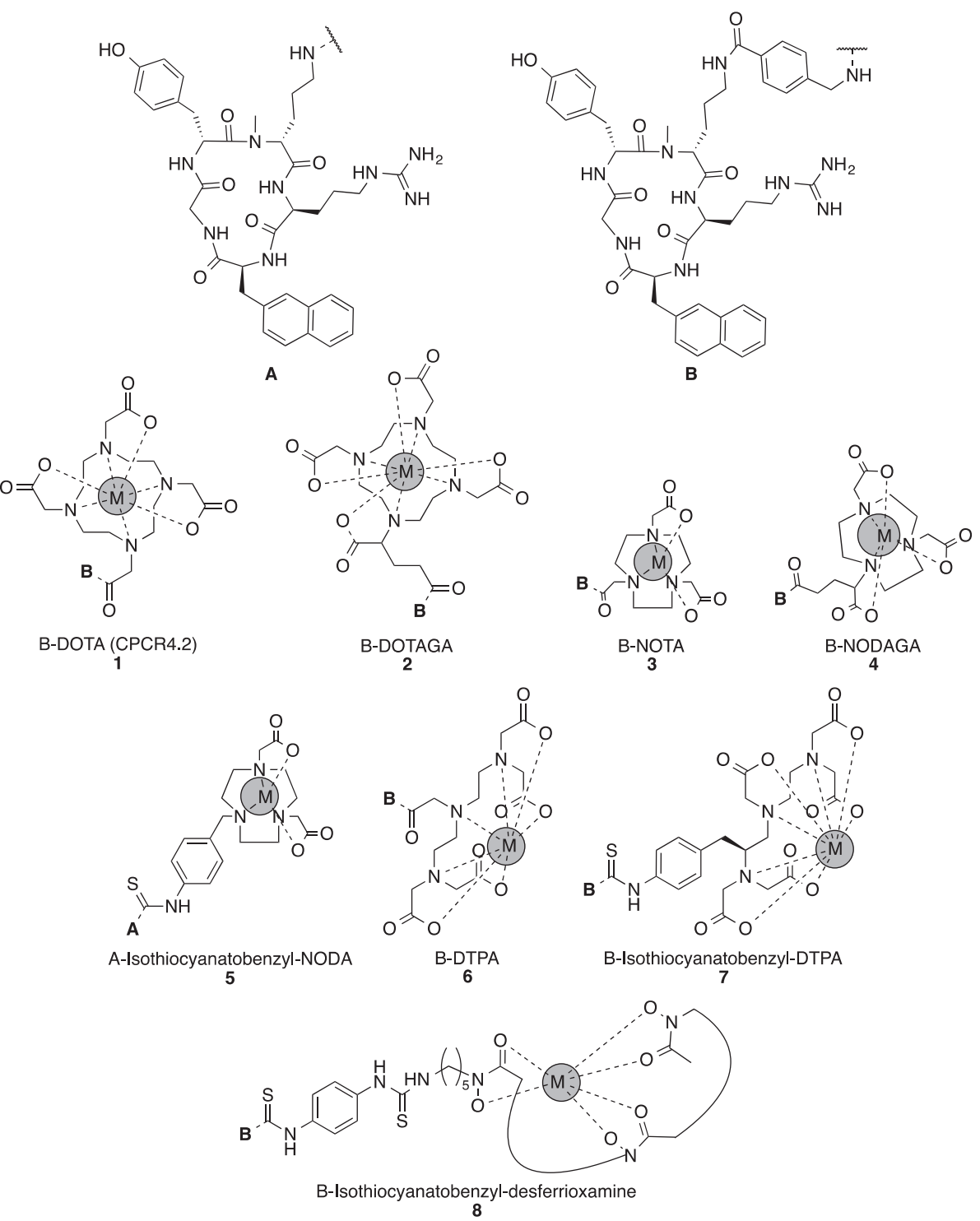

Fig. 1 Pentixafor-based analogs with different chelators and metals (M, gray). A constitutes the pentapeptide core Cyclo(-D-Tyr-N-Me-D-Orn-L-Arg-L2-Nal-Gly-) whereas B contains an additional aminomethylbenzoyl (AMB) linker between the peptide and chelator

are substantially higher than those compared to other peptidic CXCR4 imaging agents [8]. First, studies in patients suffering from lymphoproliferative diseases $[9,10]$ demonstrated its excellent properties, including a favorable dosimetry for CXCR4-receptor mapping by means of positron emission tomography (PET) [11].

Based on the success of $\left[{ }^{68} \mathrm{Ga}\right]$ pentixafor, this study aims to broaden the potential spectrum of radiometallabeled CXCR4 ligands, both for imaging and therapy, by development and in vitro evaluation of a range of tracers labeled with alternative radionuclides, such as ${ }^{111} \mathrm{In}^{3+}$ (for single photon emission computed tomography (SPECT)); ${ }^{18} \mathrm{~F}^{-}$and ${ }^{89} \mathrm{Zr}^{4+}$ (for PET); or ${ }^{90} \mathrm{Y}^{3+},{ }^{177} \mathrm{Lu}^{3+}$, and ${ }^{213} \mathrm{Bi}^{3+}$ (for endoradiotherapy).
However, the experiences gained during the development of pentixafor have shown that, compared with $\left[{ }^{68} \mathrm{Ga}\right]$ pentixafor, unlabeled pentixafor and other radiometalated pentixafor derivatives exhibit significantly lower CXCR4 receptor affinities. Thus, in contrast to other peptides, such as somatostatin receptor (SSTR), gastrin-releasing peptide receptor (GRPR), or $\alpha_{\mathrm{v}} \beta_{3}$ binding peptides, the affinity of $\left[{ }^{68} \mathrm{Ga}\right]$ pentixafor towards CXCR4 is determined by the entire ligand-spacerchelator-radiometal construct. Consequently, a more or less independent "bioactive substructure" or "pharmacophor" (e.g., the pentapeptide core A depicted in Fig. 1) cannot be identified. In this study, we investigated pentixafor derivatives with alternative cyclic and acyclic 
chelators and evaluated these ligands in vitro. With regard to the utilized chelators, the following nuclides relevant for medical purposes have been investigated: $\mathrm{Ga}^{3+}, \mathrm{AlF}^{2+}, \mathrm{Zr}^{4+}, \mathrm{Cu}^{2+}, \mathrm{In}^{3+}, \mathrm{Lu}^{3+}, \mathrm{Y}^{3+}$, and $\mathrm{Bi}^{3+}$ (Fig. 1).

\section{Methods}

\section{General}

Trityl chloride polystyrene (TCP) resins were purchased from PepChem (Tübingen, Germany) and Sigma-Aldrich (Steinheim, Germany). 9-fluorenylmethyloxycarbonyl (Fmoc) and all other protected amino acid analogs were obtained from Iris Biotech (Marktredwitz, Germany) or Bachem (Bubendorf, Switzerland). Chelators were obtained from CheMatech (Dijon, France, or Macrocyclics (Dallas, USA)) while all other chemicals were bought from Sigma-Aldrich, Fluka, or Merck (Darmstadt, Germany) if not stated otherwise. Solvents and all other organic reagents were purchased from Sigma-Aldrich (Munich, Germany), CLN (Freising, Germany), and VWR (Darmstadt, Deutschland). Water for reversed phase (RP)-HPLC was filtered through a $0.2-\mu \mathrm{m}$ filter (Thermo Scientific, Barnstead Smart2Pure, Niederelbert, Germany). Analytical RP-HPLC was performed on a Nucleosil $100 \mathrm{C} 18$ $\left(5 \mu \mathrm{m}, 125 \times 4.0 \mathrm{~mm}^{2}\right)$ column (CS GmbH, Langerwehe, Germany) using a Sykam gradient HPLC System (Sykam $\mathrm{GmbH}$, Eresing, Germany). For elution, linear gradients of acetonitrile $(0.1 \%(v / v)$ trifluoroacetic acid (TFA), solvent B) in water $(0.1 \%$ TFA $(v / v)$, solvent A) at a constant flow of $1 \mathrm{~mL} / \mathrm{min}$ over $15 \mathrm{~min}$ were used. UV detection was performed at 220 and $254 \mathrm{~nm}$ using a 206 PHD UV-vis detector (LinearTM Instruments Corporation, Reno, USA). Purities were determined at $220 \mathrm{~nm}$ using LabSolutions software by Shimadzu Corp. Preparative RP-HPLC was performed on a Sykam gradient HPLC System (Sykam $\mathrm{GmbH}$, Eresing, Germany) equipped with a Multospher $100 \mathrm{RP} 18-5\left(250 \times 20 \mathrm{~mm}^{2}\right)$ column $(\mathrm{CS} \mathrm{GmbH}$, Langerwehe, Germany) at a constant flow of $10 \mathrm{~mL} / \mathrm{min}$ using the same solvents as stated above (duration of gradient, $20 \mathrm{~min}$ ). Electrospray ionization (ESI)-mass spectra were recorded on a Varian 500-MS IT mass spectrometer (Agilent Technologies, Santa Clara, USA).

\section{General SPPS}

Peptides were synthesized manually on solid TCP support using standard Fmoc strategy and an Intelli-Mixer syringe shaker (Neolab, Heidelberg, Germany). As side chain protecting groups, N-[1-(4,4-dimethyl-2,6-dioxocyclohexylidene)ethyl] (Dde) for D-Orn and t-butyl and 2,2,4,6,7-pentamethyldihydrobenzofuran-5-sulfonyl (Pbf) groups for D-Tyr and Arg, respectively, were utilized.

O-(Benzotriazol-1-yl)-N,N,N', $\mathrm{N}^{\prime}$-tetramethyluronium tetrafluoroborate (TBTU) and N-hydroxybenzotriazole (HOBt) were used as coupling reagents. $\mathrm{N}$-alkylated amines were acylated using (1-[bis(dimethylamino)methylene]-1H- 1,2,3-triazolo[4,5-b]pyridinium 3-oxid hexafluorophosphate) (HATU) with 1-hydroxy-7-azabenzotriazole (HOAt) as racemization suppressant.

Cleavage of the peptide from the TCP support with retention of acid-labile protection groups was achieved by treating the peptidyl resin with a solution of dichloromethane (DCM):trifluoroethanol:acetic acid (6:1:3) $(v / v / v)$; for deprotection of acid-labile groups, TFA:triisopropylsilane (TIPS): $\mathrm{H}_{2} \mathrm{O}(95: 2.5: 2.5)(v / v / v)$ was used ( $2 \times 30 \mathrm{~min})$. Deprotection of Dde was carried out with $2 \%$ hydrazine monohydrate in dimethylformamide (DMF) $(v / v)$.

For Fmoc-deprotection, the peptide was treated with $20 \%$ piperidine in N-methyl-2-pyrrolidone (NMP) $(v / v)$ for $20 \mathrm{~min}$.

For general coupling of amino acids, a solution of Fmoc-Xaa-OH (1.5 equiv), TBTU (1.5 equiv), HOBt (1.5 equiv), and $\mathrm{N}, \mathrm{N}$-diisopropylethylamine (DIPEA) (5 equiv) in NMP $(1 \mathrm{~mL} / \mathrm{g}$ resin) was added to the resin-bound peptide and shaken for $90 \mathrm{~min}$ at room temperature and washed six times with NMP.

\section{Synthesis of $A$}

The peptide was synthesized according to a previously published procedure [12]. In short, synthesis was carried out using a standard Fmoc strategy using a TCP resin as solid support and HOBt/TBTU as coupling reagents. After selective $N$-methylation of D-Orn, D-Tyr was coupled to the peptide with HATU/HOAt, cleaved from the resin, and finally cyclized.

Coupling AMB to the D-Orn side chain was carried out using Fmoc- or Boc-protected AMB (1.5 equiv). AMB was preactivated with DIC $\left(\mathrm{N}, \mathrm{N}^{\prime}\right.$-diisopropyl-carbodiimide) (1.5 equiv), HOAt (1.5 equiv), and DIPEA ( 4.5 equiv) in $5 \mathrm{~mL}$ DMF for $10 \mathrm{~min}$. The D-Orn deprotected peptide precursor was dissolved in DMF, and the preactivated linker was added. After complete reaction $(2 \mathrm{~h})$, Fmoc deprotection and semi-preparative HPLC purification, appropriate chelators were coupled to the peptide. HPLC (50 to $100 \% \mathrm{~B}$ in $15 \mathrm{~min}$ ): $t_{R}=8.0 \mathrm{~min}$; ESI-mass spectra (MS): calculated for (C61H78N10O10S): 1142.5; found: $m / z=1143.6[\mathrm{M}+\mathrm{H}]^{+}$.

\section{Coupling of chelators and metal complexation}

A molar excess of the activated chelator was added to a free amino group of the peptide analog. Subsequent to successful coupling, the chelator-conjugated peptide was deprotected and purified. Metal complexation was performed in the presence of weakly chelating acetate buffers to reduce the likelihood of hydrolysis. Solutions for metal labeling comprised $\mathrm{LuCl}_{3}(20 \mathrm{mM}), \mathrm{pH}=6.0$; $\mathrm{InCl}_{3}(20 \mathrm{mM}), \mathrm{pH}=4.5$; and $\mathrm{YCl}_{3}(20 \mathrm{mM}), \mathrm{pH}=5.9$, each in ammonium acetate $(0.1 \mathrm{M})$ and $\mathrm{Ga}\left(\mathrm{NO}_{3}\right)_{3}(2 \mathrm{mM})$ $\mathrm{pH}=3.0 ; \mathrm{Cu}(\mathrm{OAc})_{2} \mathrm{pH}=6.0 ;$ and $\mathrm{ZrCl}_{4}(20 \mathrm{mM}) \mathrm{pH}=1.3$, 
each in water. The chelator-conjugated peptide $(250 \mu \mathrm{L}$, $2 \mathrm{mM}, 1$ equiv) was dissolved in $\mathrm{H}_{2} \mathrm{O}$ and DMSO up to $50 \%(v / v)$, if necessary, and the metal (1-10 equiv) was added, pH adjusted, and heated for $30 \mathrm{~min}$. Final metalated peptides were obtained in a purity $\geq 95 \%$, and used for in vitro studies without further purification, unless stated otherwise.

\section{Coupling of DOTA or NOTA}

For DOTA/NOTA derivatization, 1,4,7,10-tetraazacyclododecane-1,4,7,10-tetraacetic acid (DOTA) or 1,4,7-triazacyclononane-triacetic acid (NOTA) (1 equiv) was preactivated for $20 \mathrm{~min}$ using $\mathrm{N}$-hydroxysuccinimide (NHS) (1.25 equiv), 1-ethyl-3-(3-dimethylaminopropyl)carbodiimide (EDCI) (1.25 equiv), and DIPEA ( 2 equiv) dissolved in water $(1 \mathrm{~mL} / 0.3 \mathrm{mmol})$. The peptide $\mathbf{B}(0.25$ or 0.3 equiv, for DOTA or NOTA, respectively) was dissolved in DMF ( $1 \mathrm{~mL}$ per $0.15 \mathrm{mmol}$ of peptide) and slowly added to the reaction mixture according to a previously published protocol [13]. 3: HPLC (30 to $55 \% \mathrm{~B}$ in $15 \mathrm{~min}$ ): $t_{R}=10.1 \mathrm{~min}$; ESI-MS: calculated for (C56H73N13O12): 1119.6; found: $m / z=1121.0[\mathrm{M}+\mathrm{H}]^{+}$, $1143.0[\mathrm{M}+\mathrm{Na}]^{+}$; 1: HPLC (30 to $55 \% \mathrm{~B}$ in $\left.15 \mathrm{~min}\right): t_{R}=$ $8.8 \mathrm{~min}$; ESI-MS: calculated for (C60H80N14O14): 1220.6; found: $m / z=1221.6[\mathrm{M}+\mathrm{H}]^{+}, 1243.6[\mathrm{M}+\mathrm{Na}]^{+}$.

\section{Coupling of DOTAGA-anhydride}

2,2',2" -(10-(2,6-dioxotetrahydro-2H-pyran-3-yl)-1,4,7,10tetraazacyclododecane-1,4,7-triyl)triacetic acid (DOTAGAanhydride) (2 equiv) was dissolved in anhydrous DMF to obtain a white suspension and added to a solution of $\mathbf{B}$ (1 equiv) and triethylamine (10 equiv) in anhydrous DMF. 2: HPLC (30 to $55 \% \mathrm{~B}$ in $15 \mathrm{~min}$ ): $t_{R}=9.8 \mathrm{~min}$; ESI-MS: calculated for (C63H84N14O16): 1292.6; found: $m / z=1293.5[\mathrm{M}+\mathrm{H}]^{+}, 1315.5[\mathrm{M}+\mathrm{Na}]^{+}$.

\section{Coupling of NODAGA}

4-(4,7-bis(2-(tert-butoxy)-2-oxoethyl)-1,4,7-triaza cyclononan1-yl)-5-(tert-butoxy)-5-oxopentanoic acid ((NODAGA)(tBu $)_{3}$ ) (3 equiv) was coupled to $\mathbf{B}$ (1 equiv) using a solution of DIC (2 equiv), HOAt (2 equiv), and DIPEA (6 equiv) in anhydrous DMF. The product was fully deprotected and purified. HPLC (30 to $55 \% \mathrm{~B}$ in $15 \mathrm{~min}$ ): $t_{R}=$ $10.8 \mathrm{~min}$; ESI-MS: calculated for (C59H77N13O14): 1191.6; found: $m / z=1193.0[\mathrm{M}+\mathrm{H}]^{+}, 1215.0[\mathrm{M}+\mathrm{Na}]^{+}$.

\section{Coupling of DTPA}

3,6,9-tris(2-(tert-butoxy)-2-oxoethyl)-13,13-dimethyl-11oxo-12-oxa-3,6,9-triazatetradecan-1-oic acid (DTPA)(tBu $)_{4}$ ( 2 equiv) was coupled to $\mathbf{B}$ (1 equiv) using a solution of DIC (1.5 equiv), HOAt (1.5 equiv), and DIPEA (4.5 equiv) in anhydrous DMF. After successful coupling, the product was deprotected and purified. HPLC (30 to $60 \% \mathrm{~B}$ in $15 \mathrm{~min}$ ): $t_{R}=8.0 \mathrm{~min}$; ESI-MS: calculated for
(C58H75N13O16): 1209.6; found: $m / z=1210.8[\mathrm{M}+\mathrm{H}]^{+}$, $1232.6[\mathrm{M}+\mathrm{Na}]^{+}$.

\section{Coupling of $p-S C N-B n-D T P A$}

2-(4-isothiocyanatobenzyl)diethylenetriaminepentaacetic acid (p-SCN-Bn-DTPA) (21.0 mg, $32.4 \mu \mathrm{mol}, 1.5$ equiv) was coupled to $\mathbf{B}$ (18.0 mg, $21.6 \mu \mathrm{mol}, 1$ equiv) with DIPEA in anhydrous DMF to obtain $\mathrm{pH} \approx 9$. HPLC (30 to $60 \% \mathrm{~B}$ in $15 \mathrm{~min}$ ): $t_{R}=11.2 \mathrm{~min}$; ESI-MS: calculated for (C66H82N14O17S): 1374.6; found: $m / z=1375.8[\mathrm{M}+\mathrm{H}]^{+}$.

\section{Coupling of p-SCN-Bn-DFO}

p-Isothiocyanatobenzyl-desferoxamine (DFO-Bn-NCS) (21.0 mg, 32.4 $\mu \mathrm{mol}, 1.5$ equiv) was coupled to $\mathbf{B}$ (18.0 mg, $21.6 \mu \mathrm{mol}, 1$ equiv) in anhydrous DMF and adjusted with $\mathrm{NEt}_{3}$ to $\mathrm{pH}=9.5$. HPLC (30 to $60 \% \mathrm{~B}$ in $15 \mathrm{~min}): t_{R}=14.0 \mathrm{~min}$; ESI-MS: calculated for (C77H106N18O15S2): 1586.8; found: $m / z=1587.0$ $[\mathrm{M}+\mathrm{H}]^{+}$.

\section{Coupling of NCS-MP-NODA}

2,2' -(7-(4-isothiocyanatobenzyl)-1,4,7-triazonane-1,4diyl)diacetic acid (NCS-MP-NODA) $(1.9 \mathrm{mg}, 5.4 \mu \mathrm{mol}$, 1.5 equiv) was coupled to $\mathbf{A}$ ( $3 \mathrm{mg}, 3.6 \mu \mathrm{mol}, 1$ equiv) with DIPEA (1.1 $\mu \mathrm{L}, 3.2 \mu \mathrm{mol}, 2$ equiv) in anhydrous DMF to obtain $\mathrm{pH} \approx 9$. HPLC (20 to $50 \% \mathrm{~B}$ in $15 \mathrm{~min}): t_{R}=$ $9.0 \mathrm{~min}$; ESI-MS: calculated for (C54H71N13O10S): 1093.5; found: $m / z=1095.1[\mathrm{M}+\mathrm{H}]+, 1116.7[\mathrm{M}+\mathrm{Na}]^{+}$.

\section{Chelation of $\mathrm{Ga}^{3+}$ with DOTA, DOTAGA, NOTA, NODAGA conjugates}

A solution of $\mathrm{Ga}\left(\mathrm{NO}_{3}\right)_{3}(250 \mu \mathrm{L}, 2 \mathrm{mM}, 1$ equiv $)$ in water, $\mathrm{pH}=3.0$, was added to the chelator-conjugated peptide, (250 $\mu \mathrm{L}, 2 \mathrm{mM}, 1$ equiv) dissolved in $\mathrm{H}_{2} \mathrm{O}$ and, if necessary, in DMSO up to $50 \%(v / v)$. The final $\mathrm{pH}$ of the mixture was adjusted to $4-6$ and heated at $90{ }^{\circ} \mathrm{C}$ for $30 \mathrm{~min}$. [ ${ }^{\text {nat }} \mathrm{Ga}$ ] 1: HPLC (30 to $55 \% \mathrm{~B}$ in $15 \mathrm{~min}$ ): $t_{R}=$ $9.0 \mathrm{~min}$; ESI-MS: calculated for (C60H78GaN14O14): 1287.5; found: $m / z=1287.7[\mathrm{M}+\mathrm{H}]^{+}, 1311.7[\mathrm{M}+\mathrm{Na}]^{+}$; $\left[{ }^{\text {nat }} \mathrm{Ga}\right] 2$ : HPLC (30 to $55 \% \mathrm{~B}$ in $15 \mathrm{~min}$ ): $t_{R}=9.8 \mathrm{~min}$ (Ga); ESI-MS: calculated for (C63H82GaN14O16): 1359.5; found: $m / z=1361.3[\mathrm{M}+\mathrm{H}]^{+}, 1383.2[\mathrm{M}+\mathrm{Na}]^{+}$; [ $\left.{ }^{\text {nat }} \mathrm{Ga}\right] 3$ : HPLC (30 to $55 \% \mathrm{~B}$ in $15 \mathrm{~min}$ ): $t_{R}=9.3 \mathrm{~min}$; ESI-MS: calculated for (C56H71GaN13O12): 1186.5; found: $\left.m / z=1188.9[\mathrm{M}+\mathrm{H}]^{+}, 1209.9[\mathrm{M}+\mathrm{Na}]^{+} ;{ }^{\text {nat }} \mathrm{Ga}\right] 4$ : HPLC (30 to $55 \% \mathrm{~B}$ in $15 \mathrm{~min}$ ): $t_{R}=10.8 \mathrm{~min}$; ESI-MS: calculated for (C59H74GaN13O14): 1257.5; found: $m / z=$ $1258.8[\mathrm{M}+\mathrm{H}]^{+}$.

\section{Chelation of $\mathrm{In}^{3+}, \mathrm{Y}^{3+}$, and $\mathrm{Lu}^{3+}$ with DOTA, DOTAGA, and DTPA conjugates}

A solution of either $\mathrm{YCl}_{3}, \mathrm{LuCl}_{3}$, or $\mathrm{InCl}_{3}(250 \mu \mathrm{L}, 20 \mathrm{mM}$, 10 equiv) in ammonium acetate $(0.1 \mathrm{M}, \mathrm{pH}=6.0)$ was 
added to the chelator-conjugated peptide $(250 \mu \mathrm{L}, 2 \mathrm{mM}$, 1 equiv). The $\mathrm{pH}$ was adjusted to $4-6$, and the mixture heated at $90{ }^{\circ} \mathrm{C}$ for $\left.30 \mathrm{~min} .{ }^{\text {nat }} \mathrm{Lu}\right] \mathbf{1}$ and $\left[{ }^{\text {nat }} \mathrm{Y}\right] \mathbf{1}$ : HPLC (10 to $50 \% \mathrm{~B}$ in $15 \mathrm{~min}$ ): $t_{R}=10.7 \mathrm{~min}$ each; ESI-MS: calculated for (C60H77LuN14O14): 1392.5; found: $\mathrm{m} / z=$ $1393.8[\mathrm{M}+\mathrm{H}]^{+}$; ESI-MS: calculated for (C60H77N14O14Y): 1306.5; found: $m / z=1308.5[\mathrm{M}+\mathrm{H}]^{+}, 1329.7[\mathrm{M}+\mathrm{Na}]^{+}$; [ $\left.{ }^{\text {nat }} \mathrm{Lu}\right] 2$ and [ $\left.{ }^{\text {nat }} \mathrm{Y}\right] 2$ : HPLC (30 to $55 \% \mathrm{~B}$ in $15 \mathrm{~min}$ ): $t_{R}=$ 9.8 min each; ESI-MS: calculated for (C63H80LuN14O16): 1463.5; found: $m / z=1465.3[\mathrm{M}+\mathrm{H}]^{+}, 1488.1[\mathrm{M}+\mathrm{Na}]^{+}$; ESI-MS: calculated for (C63H80N14O16Y): 1377.5; found: $m / z=1379.3[\mathrm{M}+\mathrm{H}]^{+}, 1402.2[\mathrm{M}+\mathrm{Na}]^{+}$; $\left.{ }^{\text {nat }} \mathrm{In}\right] 7$ : HPLC (30 to $55 \% \mathrm{~B}$ in $15 \mathrm{~min}$ ): $t_{R}=10.3 \mathrm{~min}$; ESI-MS: calculated for (C66H77InN14O17S): 1484.4; found: $m / z=$ 1487.4 $[\mathrm{M}+\mathrm{H}]^{+} ;\left[{ }^{\text {nat }} \mathrm{Lu}\right] 6$, $\left[{ }^{\text {nat }} \mathrm{In}\right] 6$, and $\left[{ }^{\text {nat }} \mathrm{Y}\right] 6$ : HPLC (30 to $60 \% \mathrm{~B}$ in $15 \mathrm{~min}$ ): $t_{R}=9.1 \mathrm{~min}$ each; ESI-MS: calculated for (C58H71LuN13O16): 1380.5; found: $\mathrm{m} / z=$ $1382.8[\mathrm{M}+\mathrm{H}]^{+}$, for (C58H71N13O16Y): 1294.4; found: $m / z=1296.7[\mathrm{M}+\mathrm{H}]^{+}$, for (C58H71InN13O16): 1320.4; found: $m / z=1322.9,[\mathrm{M}+\mathrm{H}]^{+}, 1344.9[\mathrm{M}+\mathrm{Na}]^{+}$.

\section{Chelation of $\mathrm{Zr}^{4+}$ with 8}

To obtain [ ${ }^{\text {nat }} \mathrm{Zr}$ ]8, a solution of $\mathrm{ZrCl}_{4}$ in water $(\mathrm{pH}=1.3)$ (20 $\mathrm{mM})$ was added to the DFO-bearing peptide (2 $\mathrm{mM})$. Quantitative complexation at room temperature occurred within a few minutes without forming any side products. HPLC (30 to $60 \% \mathrm{~B}$ in $15 \mathrm{~min}$ ): $t_{R}=14.0 \mathrm{~min}$; ESI-MS: calculated for (C77H103N18O15S2Zr): 1673.6; found: $m / z=1674.5[\mathrm{M}+\mathrm{H}]^{+}$.

\section{Chelation of $\mathrm{Bi}^{3+}$ with DOTA and DOTAGA conjugates}

$\left[{ }^{\text {nat }} \mathrm{Bi}\right] \mathbf{1}$ and $\left[{ }^{\text {nat }} \mathrm{Bi}\right] \mathbf{2}$ were prepared by the dropwise addition of ${ }^{\text {nat }} \mathrm{Bi}\left(\mathrm{H}_{3} \mathrm{CCOO}\right)_{3}$ (10 equiv) to a solution of DOTA or DOTAGA-peptide at $\mathrm{pH} \sim 5$. $\left[{ }^{\text {nat }} \mathrm{Bi}\right] \mathbf{1}$ : HPLC (30 to $55 \%$ B in $15 \mathrm{~min}$ ): $t_{R}=8.8 \mathrm{~min}$; ESI-MS: calculated for (C60H77BiN14O14): 1426.6; found: $\mathrm{m} / z=1427.4$ $[\mathrm{M}+\mathrm{H}]^{+}, \quad 1451.5[\mathrm{M}+\mathrm{Na}]^{+}, 1465.1[\mathrm{M}+\mathrm{K}]^{+} ; \quad\left[{ }^{\text {nat }} \mathrm{Bi}\right] 2$ : HPLC (30 to $55 \% \mathrm{~B}$ in $15 \mathrm{~min}$ ): $t_{R}=9.8 \mathrm{~min}$; ESI-MS: calculated for (C63H80BiN14O16): 1497.6; found: $\mathrm{m} / z=$ $1499.3[\mathrm{M}+\mathrm{H}]^{+}, 1521.3[\mathrm{M}+\mathrm{Na}]^{+}, 1537.3[\mathrm{M}+\mathrm{K}]^{+}$.

\section{Chelation of $\mathrm{Cu}^{2+}$ with DOTA, DOTAGA, NOTA, NODAGA, and DTPA conjugates}

A solution of $\mathrm{Cu}(\mathrm{OAc})_{2}(250 \mu \mathrm{L}, 2 \mathrm{mM}, 1$ equiv $)$ in water, $\mathrm{pH}=6.0$, was added to the chelator-conjugated peptide, ( $250 \mu \mathrm{L}, 2 \mathrm{mM}, 1$ equiv). The mixture was incubated at room temperature for $30 \mathrm{~min}$. HPLC revealed quantitative complexation. $\left[{ }^{\text {nat }} \mathrm{Cu}\right] 1$ : $\mathrm{HPLC}$ (30 to $55 \%$ $\mathrm{B}$ in $15 \mathrm{~min}$ ): $t_{R}=10.8 \mathrm{~min}$; ESI-MS: calculated for (C60H77CuN14O14): 1280.5; found: $m / z=1282.8[\mathrm{M}+\mathrm{H}]^{+}$, $1306.8[\mathrm{M}+\mathrm{Na}]^{+}$.

$\left[{ }^{\text {nat }} \mathrm{Cu}\right] 2$ : HPLC (30 to $55 \% \mathrm{~B}$ in $\left.15 \mathrm{~min}\right): t_{R}=$ $11.0 \mathrm{~min}$; ESI-MS: calculated for (C63H82CuN14O16): 1353.5; found: $m / z=1354.8[\mathrm{M}+\mathrm{H}]^{+}, 1377.8[\mathrm{M}+\mathrm{Na}]^{+}$; $\left[{ }^{\text {nat }} \mathrm{Cu}\right] 3$ : HPLC (30 to $55 \% \mathrm{~B}$ in $15 \mathrm{~min}$ ): $t_{R}=10.5 \mathrm{~min}$; ESI-MS: calculated for (C56H71CuN13O12): 1180.5; found: $\left.m / z=1181.8[\mathrm{M}+\mathrm{H}]^{+}, 1203.6[\mathrm{M}+\mathrm{Na}]^{+} ;{ }^{\text {nat }} \mathrm{Cu}\right] 4$ : HPLC (30 to $55 \% \mathrm{~B}$ in $15 \mathrm{~min}$ ): $t_{R}=10.9 \mathrm{~min}$; ESI-MS: calculated for (C59H74CuN13O14): 1251.5; found: $m / z=1253.8[\mathrm{M}+\mathrm{H}]^{+}$; $\left[{ }^{\text {nat }} \mathrm{Cu}\right] 6$ : HPLC (30 to $55 \% \mathrm{~B}$ in $15 \mathrm{~min}$ ): $t_{R}=9.8 \mathrm{~min}$; ESI-MS: calculated for (C58H72CuN13O16): 1269.5; found: $m / z=1271.7[\mathrm{M}+\mathrm{H}]^{+}$, $1232.8[\mathrm{M}+\mathrm{Na}]^{+}$.

\section{Chelation of $\mathrm{AlF}^{2+}$ with NOTA and NODA conjugates}

The peptide was labeled with [ $\left.{ }^{\text {nat }} \mathrm{F}\right] \mathrm{AlF}$ by mixing $\mathrm{AlCl}_{3}$ (1.2 equiv, $0.468 \mu \mathrm{mol}$ in $0.5 \mathrm{M} \mathrm{NaOAc}, \mathrm{pH}=4.0$ ), $\mathrm{NaF}$ (1.2 equiv $0.468 \mu \mathrm{mol}$ in $0.5 \mathrm{M}$ sodium acetate, $\mathrm{pH}=4.0$ ) with 3 or 5 ( 1 equiv, $0.39 \mu \mathrm{mol})$. The $\left[{ }^{\text {nat }} \mathrm{F}\right]$ AlF-labeled peptide was purified using RP-HPLC on a $\mathrm{C}_{18}(5 \mu \mathrm{m}$, $125 \times 4.0 \mathrm{~mm})$. [ ${ }^{\text {nat }} \mathrm{F}$ ]AlF-3: HPLC (23 \% B in $\left.15 \mathrm{~min}\right): t_{R}=$ $10.5 \mathrm{~min}$; ESI-MS: calculated for (C56H71AlFN13O12): 1163.5; found: $\left.m / z=1164.9[\mathrm{M}+\mathrm{H}]^{+} ;{ }^{\text {nat }} \mathrm{F}\right] \mathrm{AlF}-5$ : HPLC (20 to $50 \% \mathrm{~B}$ in $15 \mathrm{~min}$ ): $t_{R}=8.2 \mathrm{~min}$; ESI-MS: calculated for (C54H69AlFN13O10S): 1137.5; found: $m / z=1139.0$ $[\mathrm{M}+\mathrm{H}]^{+}, 1160.9[\mathrm{M}+\mathrm{Na}]^{+}$.

\section{Cell culture and determination of CXCR4 receptor affinity $\left(I C_{50}\right)$}

For in vitro experiments, the Jurkat $\mathrm{T}$ - cell line was used. The cells were maintained in RPMI 1640 medium (Biochrom) containing $10 \%$ fetal calf serum (FCS) (Biochrom). The cell line was cultured at $37{ }^{\circ} \mathrm{C}$ in a humidified atmosphere with $5 \% \mathrm{CO}_{2}$ and passaged two to three times a week, depending on the cell count.

CXCR4 affinities were determined in competitive binding assays using Jurkat cells with $\left[{ }^{125} \mathrm{I}\right] \mathrm{FC} 131$ as the radioligand according to a protocol similar to previously published [7]. FC131 (cyclo(-D-Tyr-L-Arg-L-Arg-L-NalGly-)) [14] was synthesized and iodinated as described previously [7]. Jurkat cells $\left(4 \times 10^{5}\right.$ cells per vial) were incubated with the respective peptide of interest at the final concentrations ranging from $10^{-11}$ to $10^{-5} \mathrm{M}$ and app. $0.1 \mathrm{nM}$ of $\left[{ }^{125} \mathrm{I}\right] \mathrm{FC} 131$. The total sample volume was $250 \mu \mathrm{L}$. After an incubation time of $120 \mathrm{~min}$, the vials were centrifuged at $1300 \mathrm{rpm}$ (Heraeus Megafuge, Thermo) for $3 \mathrm{~min}$ and the supernatant was removed. The cells were washed twice with $200 \mu \mathrm{L}$ ice-cold Hank's balanced salt solution (HBSS). After each washing step, the samples were centrifuged and the supernatant removed. Finally, the amount of displaced and bound radioligand in the combined fractions of the supernatant and the cell pellet was quantified. The half maximal inhibitory concentration $\left(\mathrm{IC}_{50}\right)$ values were determined using GraphPad Prism software. 


\section{Results}

Based on the promising results of $\left[{ }^{68} \mathrm{Ga}\right]$ pentixafor $[7-11$, 15], the influence of different pentixafor-based peptidelinker-chelators on the CXCR4 affinity $\left(\mathrm{IC}_{50}\right)$ has been evaluated. For this purpose, seven different chelators have been coupled via an AMB moiety to the D-Orn side chain of the CPCR4.2 core peptide A (Fig. 1): (a) DOTA, (b) DOTAGA, (c) NOTA, (d) 1,4,7-triazacyclononane,1-glutaric acid-4,7-acetic acid (NODAGA), (e) DTPA, (f) p-SCNBn-DTPA, (g) p-SCN-Bn-Desferrioxamine (DFO), and (h) p-SCN-Bn-NODA, whereby SCN-Bn-NODA was directly coupled to the pentapeptide core without ABS. Depending on the preferred metals for each chelator, reference $\mathrm{Ga}^{3+}$, complexes with $\mathrm{AlF}^{2+}, \mathrm{Zr}^{4+}, \mathrm{Cu}^{2+}, \mathrm{In}^{3+}, \mathrm{Lu}^{3+}, \mathrm{Y}^{3+}$, and $\mathrm{Bi}^{3+}$ were prepared and evaluated in competitive binding assays on Jurkat T - cells with $\left.{ }^{[125} \mathrm{I}\right] \mathrm{FC} 131$ as the radioactive reference (Table 1).

As already demonstrated $[7,8]$, non-metalated pentixafor (1) shows low affinity $\left(\mathrm{IC}_{50}: 102 \pm 17 \mathrm{nM}\right)$ towards CXCR4, whereas the $\mathrm{Lu}^{3+}$ and $\mathrm{Y}^{3+}$ complexes $\left(\mathrm{IC}_{50}\right.$ : $40.9 \pm 12$ and $40.8 \pm 27 \mathrm{nM}$, respectively) exhibit affinities quite similar to [ ${ }^{\text {nat }}$ In] pentixafor $\left(\mathrm{IC}_{50}: 44 \pm 4 \mathrm{nM}\right.$ ) [7]. Surprisingly, the affinity of the $\mathrm{Bi}^{3+}$ complex is even higher $\left(\mathrm{IC}_{50}: 22.1 \pm 7.0 \mathrm{nM}\right)$ than the affinity of $\left[{ }^{\text {nat }} \mathrm{Ga}\right]-$ pentixafor $\left(\mathrm{IC}_{50}: 24.6 \pm 2.5 \mathrm{nM}\right)$ thus making $\left[{ }^{213} \mathrm{Bi}\right]$ pentixafor an attractive $\alpha$-particle emitting therapeutic analog for endoradiotherapy. The affinity of the corresponding $\mathrm{Cu}^{2+}$ complex was low $(131 \pm 11 \mathrm{nM})$. With regard to previous reports [7], it is important to notice

Table $1 \mathrm{IC}_{50}$ values of different metal-chelate conjugates consisting of cyclo(-D-Tyr-N-Me-D-Orn(spacer- $\left[\mathrm{M}^{3+}\right]$ chelator)-L-Arg-L-2Nal-Gly-), expressed as mean \pm SD $(n=3)$

\begin{tabular}{|c|c|c|c|}
\hline Compound & $\mathrm{IC}_{50} / \mathrm{nM}$ & Compound & $\mathrm{IC}_{50} / \mathrm{nM}$ \\
\hline 1 (DOTA) & $102 \pm 17$ & 2 (DOTAGA) & $654 \pm 263$ \\
\hline$\left[{ }^{\text {nat }} \mathrm{Ga}^{3+}\right] \mathbf{1}$ & $24.8 \pm 2.5$ & {$\left[{ }^{\text {nat }} \mathrm{Ga}^{3+}\right] 2$} & $380 \pm 102$ \\
\hline$\left[{ }^{\text {nat }} \mathrm{Bi}^{3+}\right] \mathbf{1}$ & $22.1 \pm 7.0$ & {$\left[{ }^{\text {nat }} \mathrm{Bi}^{3+}\right] \mathbf{2}$} & $29.4 \pm 7.6$ \\
\hline$\left[{ }^{\text {nat }} \mathrm{Cu}^{2+}\right] \mathbf{1}$ & $131 \pm 11$ & {$\left[{ }^{\text {nat }} \mathrm{Cu}^{2+}\right] 2$} & $1165 \pm 220$ \\
\hline$\left[{ }^{\text {nat }} \mathrm{Lu}^{3+}\right] \mathbf{1}$ & $40.9 \pm 12$ & {$\left[{ }^{\text {nat }} \mathrm{Lu}^{3+}\right] \mathbf{2}$} & $188 \pm 2.8$ \\
\hline$\left[{ }^{\text {nat }} Y^{3+}\right] \mathbf{1}$ & $40.8 \pm 27$ & {$\left[{ }^{\text {nat }} Y^{3+}\right] 2$} & $126 \pm 89$ \\
\hline 3 (NOTA) & $253 \pm 49$ & 4 (NODAGA) & $275 \pm 106$ \\
\hline$\left[{ }^{\text {nat }} \mathrm{Ga}^{3+}\right] \mathbf{3}$ & $17.8 \pm 7.7$ & {$\left[{ }^{\text {nat }} \mathrm{Ga}^{3+}\right] \mathbf{4}$} & $342 \pm 72$ \\
\hline$\left[{ }^{\text {nat }} \mathrm{Cu}^{2+}\right] \mathbf{3}$ & $46.1 \pm 26$ & {$\left[{ }^{\text {nat }} \mathrm{Cu}^{2+}\right] \mathbf{4}$} & $343 \pm 10$ \\
\hline$\left[{ }^{\text {nat }}\right.$ F]AIF-3 & $220 \pm 57$ & & \\
\hline 5 (SCN-Bn-NODA) & $115 \pm 24$ & 6 (DTPA) & $53 \pm 7.9$ \\
\hline$\left[{ }^{\text {nat }}\right.$ F]AIF-5 & $329 \pm 49$ & {$\left[{ }^{\text {nat }} Y^{3+}\right] 6$} & $156 \pm 6.7$ \\
\hline 7 (SCN-Bn-DTPA) & $200 \pm 73$ & {$\left[{ }^{\text {nat }} \mathrm{Lu}^{3+}\right] 6$} & $111 \pm 77$ \\
\hline$\left[{ }^{n a t} \mid n^{3+}\right] 7$ & $74.1 \pm 2.4$ & {$\left[{ }^{n a t} / n^{3+}\right] 6$} & $90 \pm 42$ \\
\hline 8 (SCN-Bn-DFO) & $105 \pm 35$ & {$\left[{ }^{\text {nat }} \mathrm{Cu}^{2+}\right] 6$} & $175 \pm 66$ \\
\hline$\left[{ }^{\text {nat }} \mathrm{Zr}^{4+}\right] \mathbf{8}$ & $148 \pm 27$ & & \\
\hline
\end{tabular}

FC131 as control $9.9 \pm 2.4 \mathrm{nM}$ that absolute $\mathrm{IC}_{50}$ values for $\left[{ }^{\text {nat }} \mathrm{Ga}\right.$ ]pentixafor differ because higher cell numbers were used for the $\mathrm{IC}_{50}$ experiments in this study $\left(4 \times 10^{5}\right.$ vs $2 \times 10^{5}$ cells/sample).

When switching to the corresponding DOTAGA derivatives, the $\mathrm{IC}_{50}$ values indicate a similar order within the series of investigated metal complexes with generally lower affinities (Table 1), except the $\mathrm{Bi}^{3+}$-complex, which, again surprisingly, showed only a small decrease of CXCR4 affinity. Thus, with respect to receptor affinity, DOTAGApentixafor was found to offer no advantage over DOTApentixafor analogs.

A corresponding evaluation of the NOTA and NODAGA derivatives identified $\left[{ }^{\text {nat }} \mathrm{Ga}^{3+}\right] 3$ as the ligand with the highest affinity in this study $\left(\mathrm{IC}_{50}: 17.8 \pm 7.7 \mathrm{nM}\right)$. All other complexes, including the $\left[{ }^{\text {nat }} F\right]$ AlF-NOTA derivative, seem to be unsuitable for further preclinical evaluation or potential clinical application. Similar disappointing results were obtained for NODA-Bn-SCN, DTPA, DTPA-Bn-SCN, and DFO-BN-SCN derivatives.

\section{Discussion}

Experiences in the development of CXCR4-targeting peptides showed that affinities to the CXCR4 receptor can be significantly affected by even moderate structural modifications in the pentapeptide core [16-19], the linker unit [20], or the chelate $[7,8]$. This is in contrast to previous experiences of GPCR, glycoprotein, or enzymetargeting peptides, such as SSTRs, GRPRs (bombesin), and integrins (e.g., $\alpha v \beta_{3}$, RGD peptides), as well as the prostatespecific membrane antigen (PSMA), to mention only a few. A variety of peptides towards these targets have been developed and-unlike CXCR4-conjugated with a broad spectrum of linker/chelator moieties. For $\alpha v \beta_{3}$ binding RGD peptides, the Lys side chain of the typically used c(Arg-Gly-Asp-D-Phe-Lys) does not influence the binding of the peptide in the cleft between the two $\alpha_{v}$ and $\beta_{3}$ subunits that forms the heterodimeric transmembrane glycoprotein [21]. Thus, these RGD peptides tolerate the introduction of spacers and chelator or the formation of multimers, such as dimers, tetramers, and octamers [22, 23]. Similar freedom of variation, although not that multifarious, has been found for SST ligands. $\mathrm{Tyr}^{3}$-octreotate for instance was conjugated to both DTPA and DOTA and labeled with ${ }^{\text {nat }} \mathrm{In},{ }^{\text {nat }} \mathrm{Ga}$, or ${ }^{\text {nat }} \mathrm{Y}$. All conjugates, including metal-free octreotate bound hSST2 with high affinity ( 0.2 to $3.9 \mathrm{nM})$, regardless of the chelator and metal used [24]. This was confirmed by other SST2 binding peptides, coupled to NODAGA, CB-TE2A, or DOTA and labeled with ${ }^{\text {nat }} \mathrm{Ga}$ or ${ }^{\text {nat }} \mathrm{Cu}$ resulting in affinities in a range from 1.3 to $12.5 \mathrm{nM}$ [25]. Moreover, modification of $\mathrm{Tyr}^{3}$-octreotate by glucose or cellobiose and 4- $\left[{ }^{18} \mathrm{~F}\right]$ fluorobenzaldehyde or 2-fluoropropionic acid resulted in almost unchanged SST2 affinities in the range of 1.3 to $3.1 \mathrm{nM}$ 
[26]. Hence, compared to CXCR4-binding pentixafor derivatives, where discrepancies varied from 17.6 to $1165 \mathrm{nM}$ (Ga-NOTA and Cu-DOTAGA conjugated to the same highly affine scaffold of CPCR4.2), the effect of chelator and metal exchange was much less pronounced.

Profound investigations on bombesin-receptor mediated imaging agents have shown that bombesin analogs can be conjugated and labeled with a broad range of chelators and metals under retention of their receptor affinity [27]. Smith et al. listed 12 bombesin conjugates, labeled with a variety of metal chelation systems, all of them with an unchanged affinity in the range of 0.5 to $10.5 \mathrm{nM}[28,29]$.

Regarding PSMA, $14{ }^{99 \mathrm{~m}}$ Tc-based imaging agents and five copper compounds were investigated with various common chelators of ${ }^{99 \mathrm{~m}} \mathrm{Tc}$ and ${ }^{64} \mathrm{Cu}$, resulting in high affinity for every compound with $K_{\mathrm{i}}$ values ranging from 0.03 to $16.3 \mathrm{nM}$ [30] and 0.19 to $13.26 \mathrm{nM}$ [31] for Tc and $\mathrm{Cu}$ compounds, respectively. Free, $\mathrm{Ga}^{3+}$, and $\mathrm{Lu}^{3}$ ${ }^{+}$-labeled PSMA DOTA and DOTAGA conjugates were shown to be highly specific as well, ranging from 10.2 to $54.7 \mathrm{nM}$ [32]. This list can be prolonged with ${ }^{18} \mathrm{~F}$-tracers developed by Pomper et al. [33, 34] and other further ${ }^{68}$ Ga-tracers developed by Eder et al. [35, 36].

Although different groups used different models for affinity evaluation, the relative trend shows that, in contrast to the examples above, the CXCR4 affinity is strongly influenced by the entire ligand-spacer-chelatorradiometal construct. During the development of linkerbridged dimers, Demmer et al. could demonstrate that even dimers, consisting of one high affinity and one "non-" CXCR4-binding peptide exhibit higher affinity when compared with the high affinity monomer conjugated with the used linker [20]. The authors conclude a subsite binding of the second peptide unit close to the main binding pocket. Based on the results of this study, we conclude that binding of the AMB- $\left[\mathrm{M}^{3+}\right]$ chelator moiety of $\left[{ }^{\text {nat }} \mathrm{Ga}\right]$ pentixafor and $\left[{ }^{\text {nat }} \mathrm{Ga}^{3+}\right] \mathbf{3}$ significantly contributes to and is a prerequisite for high affinity binding of the entire peptide ligand. Consequently, depending on the chelator, metalation can have a significant effect on the affinity towards CXCR4.

\section{Conclusions}

In summary, these studies demonstrated that pentixafor, consisting of the cyclic peptide cyclo(-D-Tyr-N-Me-DOrn-L-Arg-L-2-Nal-Gly-) and conjugated at the Orn side chain with AMB- $\left[{ }^{\text {nat }} \mathrm{Ga}\right] \mathrm{DOTA}$, represents a highly optimized ligand. As a result of this study, two further ligands, a Ga-NOTA ([ $\left.\left.{ }^{\text {nat }} \mathrm{Ga}^{3+}\right] \mathbf{3}\right)$ and a Bi-DOTA $\left(\left[{ }^{\text {nat }} \mathrm{Bi}^{3+}\right] \mathbf{1}\right)$ derivative with slightly higher affinity to hCXCR4, have been developed. Whereas the $\mathrm{Ga}^{3+}$-ligand $\left[{ }^{\text {nat }} \mathrm{Ga}^{3+}\right] 3$ suffers from a lower hydrophilicity and thus presumably inferior pharmacokinetics compared to $\left[{ }^{\text {nat }} \mathrm{Ga}\right]$ pentixafor, the $\mathrm{Bi}^{3+}$-complex is expected to be a very promising new ligand for further studies towards $\alpha$-emitter-based endoradiotherapeutic approaches, including multiple myeloma and other lymphoproliferative disorders.

\section{Abbreviations}

(NODAGA)(tBu) 3: 4-(4,7-bis(2-(tert-butoxy)-2-oxoethyl)-1,4,7-triazacyclononane1-yl)-5(tert-butoxy)-5-oxopentanoic acid; AMB: aminomethylbenzoyl; CXCR4: chemokine receptor 4; DCM: dichloromethane; Dde: N-[1-(4,4dimethyl-2,6-dioxocyclohexylidene)ethyl]; DIC: N,N'-diisopropyl-carbodiimide; DIPEA: N,N-diisopropylethylamine; DMF: dimethylformamide; DOTA: 1,4,7,

10-tetraazacyclododecane-1,4,7,10-tetraacetic acid; DOTAGA: 1,4,7,10tetraazacyclododecane,1-(glutaric acid)-4,7,10-triacetic acid; DOTAGAanhydride: 2,2',2"-(10-(2,6-dioxotetrahydro-2H-pyran-3-yl)-1,4,7,10tetraazacyclododecane-1,4,7-triyl)triacetic acid;

DTPA: diethylenetriaminepentaacetic acid; DTPA(tBu) 4: 3,6,9-tris(2-(tertbutoxy)-2-oxoethyl)-13,13-dimethyl-11-oxo-12-oxa-3,6,9-triazatetradecan-1-oic acid; EDCl: 1-ethyl-3-(3-dimethylaminopropyl)carbodiimide; FCS: fetal calf serum; Fmoc: fluorenylmethyloxycarbonyl; GRPR: gastrin-releasing peptide receptor; HATU: 1-[bis(dimethylamino)methylene]-1H-1,2,3-triazolo[4,5b]pyridinium 3-oxid hexafluorophosphate; HBSS: Hank's balanced salt solution; HOAt: 1-hydroxy-7-azabenzotriazole; HOBt: N-hydroxybenzotriazole; $\mathrm{IC}_{50}$ : half maximal inhibitory concentration; NCS-MP-NODA: 2,2'-(7-(4isothiocyanatobenzyl)-1,4,7-triazonane-1,4-diyl)diacetic acid; NHS: N-hydroxysuccinimide; NMP: N-methyl-2-pyrrolidone; NODAGA: 1,4,7triazacyclononane,1-glutaric acid-4,7-acetic acid; NOTA: 1,4,7-

triazacyclononane-triacetic acid; Pbf: 2,2,4,6,7-pentamethyldihydrobenzofuran5-sulfonyl; Pentixafor: cyclo(-D-Tyr-N-Me-D-Orn(AMB-DOTA)-L-Arg-L-2-Nal-Gly-); PET: positron emission tomography; p-SCN-Bn-DFO: (4-isothiocyanatophenyl)-3[6,17-dihydroxy-7,10,18,21-tetraoxo-27-(N-acetylhydroxylamino)-6,11,17,22tetraazaheptaeicosine] thiourea; p-SCN-Bn-DTPA: 2-(4-isothiocyanatobenzyl)diethylenetriamine pentaacetic acid; PSMA: prostate-specific membrane antigen; SDF-1: stromal cell derived factor-1; SPECT: single photon emission computed tomography; SPPS: solid-phase peptide synthesis; SSTR: somatostatin receptors; TBTU: O-(benzotriazol-1-yl)-N,N,N',N'-tetramethyluronium tetrafluoroborate; TCP: trityl chloride polystyrene; TFA: trifluoroacetic acid; TIPS: triisopropylsilane.

\section{Competing interests}

The authors declare that they have no competing interests.

\section{Authors' contributions}

AP planned and carried out the synthesis and in vitro evaluation of the compounds. MS participated in the design of the study, contributed to data interpretation, and revised the manuscript. MS helped with coordination of the experiments, and HJW helped analyzing and interpreting the data and revised the manuscript. HK and HJW initiated and designed the study. All authors approved the final manuscript.

\section{Acknowledgements}

The research leading to these results has received funding from the Deutsche Forschungsgemeinschaft (DFG) under Grant Agreement No. SFB 824 project Z1 and B5. The authors thank V. Felber, S. Hintze, and M. Konrad for synthetic assistance and [ ${ }^{\text {nat }}$ F]AIF-labeling of NOTA- and NODA-ligands and M. Wirtz and J. Notni for supportive discussions.

\section{Author details}

${ }^{1}$ Pharmaceutical Radiochemistry, Technical University Munich, Walther-Meißner-Str.3, 85748 Garching, Germany. ${ }^{2}$ Department of Nuclear Medicine, Technical University Munich, Klinikum rechts der Isar, Ismaninger Straße 22, 81675 Munich, Germany. ${ }^{3}$ Institute for Advanced Study at the Department Chemie, Technical University Munich, Lichtenbergstr. 2a, 85748 Garching, Germany.

Received: 2 March 2016 Accepted: 18 April 2016

Published online: 26 April 2016

\section{References}

1. Kucia M, Reca R, Miekus K, Wanzeck J, Wojakowski W, Janowska-Wieczorek A, et al. Trafficking of normal stem cells and metastasis of cancer stem cells involve similar mechanisms: pivotal role of the SDF-1-CXCR4 axis. Stem Cells. 2005;23(7):879-94. doi:10.1634/stemcells.2004-0342. 
2. Burger JA, Kipps TJ. CXCR4: a key receptor in the crosstalk between tumor cells and their microenvironment. Blood. 2006;107(5):1761-7. doi:10.1182/ Blood-2005-08-3182.

3. Kuil J, Buckle T, van Leeuwen FW. Imaging agents for the chemokine receptor 4 (CXCR4). Chem Soc Rev. 2012;41(15):5239-61. doi:10.1039/c2cs35085h.

4. Weiss ID, Jacobson O. Molecular imaging of chemokine receptor CXCR4 Theranostics. 2013;3(1):76-84. doi:10.7150/thno.4835.

5. Woodard LE, Nimmagadda S. CXCR4-based imaging agents. J Nucl Med. 2011;52(11):1665-9. doi:10.2967/jnumed.111.097733.

6. Feng Y, Broder CC, Kennedy PE, Berger EA. HIV-1 entry cofactor: functional cDNA cloning of a seven-transmembrane, $G$ protein-coupled receptor. Science. 1996;272(5263):872-7. doi:10.1126/science.272.5263.872.

7. Demmer O, Gourni E, Schumacher U, Kessler H, Wester HJ. PET imaging of CXCR4 receptors in cancer by a new optimized ligand. Chemmedchem. 2011;6(10):1789-91. doi:10.1002/Cmdc.201100320.

8. Gourni E, Demmer O, Schottelius M, D'Alessandria C, Schulz S, Dijkgraaf I, et al. PET of CXCR4 expression by a (68)Ga-labeled highly specific targeted contrast agent. J Nucl Med. 2011;52(11):1803-10. doi:10.2967/jnumed.111.098798.

9. Philipp-Abbrederis K, Herrmann K, Knop S, Schottelius M, Eiber M, Luckerath $K$, et al. In vivo molecular imaging of chemokine receptor CXCR4 expression in patients with advanced multiple myeloma. EMBO Mol Med. 2015;7(4): 477-87. doi:10.15252/emmm.201404698.

10. Wester HJ, Keller U, Schottelius M, Beer A, Philipp-Abbrederis K, Hoffmann F, et al. Disclosing the CXCR4 expression in lymphoproliferative diseases by targeted molecular imaging. Theranostics. 2015:5(6):618-30. doi:10.7150/thno.11251.

11. Herrmann K, Lapa C, Wester HJ, Schottelius M, Schiepers C, Eberlein U, et al. Biodistribution and radiation dosimetry for the chemokine receptor CXCR4-targeting probe 68Ga-pentixafor. J Nucl Med. 2015;56(3):410-6. doi:10.2967/jnumed.114.151647.

12. Demmer O, Dijkgraaf I, Schottelius M, Wester HJ, Kessler H. Introduction of functional groups into peptides via N-alkylation. Org Lett. 2008;10(10):2015-8. doi:10.1021/01800654n.

13. Schottelius M, Schwaiger M, Wester HJ. Rapid and high-yield solution-phase synthesis of DOTA-Tyr(3)-octreotide and DOTA-Tyr(3)-octreotate using unprotected DOTA. Tetrahedron Lett. 2003;44(11):2393-6. doi:10.1016/ S0040-4039(03)00221-1

14. Fujii N, Oishi S, Hiramatsu K, Araki T, Ueda S, Tamamura H, et al. Molecularsize reduction of a potent CXCR4-chemokine antagonist using orthogonal combination of conformation- and sequence-based libraries. Angew Chem. 2003:42(28):3251-3. doi:10.1002/anie.200351024.

15. Dijkgraaf I, Demmer O, Schumacher U, Feldhaus S, Anton M, Brandau W, et al. CXCR4 receptor targeting for in-vivo imaging of metastases. J Nucl Med Meeting Abstracts. 2008;49:103P-b.

16. Mungalpara J, Zachariassen ZG, Thiele S, Rosenkilde MM, Vabeno J. Structureactivity relationship studies of the aromatic positions in cyclopentapeptide CXCR4 antagonists. Org Biomol Chem. 2013. doi:10.1039/c3ob41941j.

17. Mungalpara J, Thiele S, Eriksen O, Eksteen J, Rosenkilde MM, Vabeno J. Rational design of conformationally constrained cyclopentapeptide antagonists for C-X-C chemokine receptor 4 (CXCR4). J Med Chem. 2012; 55(22):10287-91. doi:10.1021/Jm300926y.

18. Debnath B, Xu S, Grande F, Garofalo A, Neamati N. Small molecule inhibitors of CXCR4. Theranostics. 2013;3(1):47-75. doi:10.7150/thno.5376.

19. Demmer O, Frank AO, Hagn F, Schottelius M, Marinelli L, Cosconati S, et al. A conformationally frozen peptoid boosts CXCR4 affinity and anti-HIV activity. Angew Chem. 2012;51(32):8110-3. doi:10.1002/anie.201202090.

20. Demmer O, Dijkgraaf I, Schumacher U, Marinelli L, Cosconati S, Gourni E, et al. Design, synthesis, and functionalization of dimeric peptides targeting chemokine receptor CXCR4. J Med Chem. 2011;54(21):7648-62. doi:10.1021/Jm2009716.

21. Haubner R, Gratias R, Diefenbach B, Goodman SL, Jonczyk A, Kessler H Structural and functional aspects of RGD-containing cyclic pentapeptides as highly potent and selective integrin aVß3 antagonists. J Am Chem Soc. 1996;118(32):7461-72. doi:10.1021/ja9603721.

22. Poethko T, Schottelius M, Thumshirn G, Herz M, Haubner R, Henriksen G, et al. Chemoselective pre-conjugate radiohalogenation of unprotected monoand multimeric peptides via oxime formation. Radiochim Acta. 2004;92(4-6): 317-27. doi:10.1524/ract.92.4.317.35591.

23. Schottelius $M$, Wester HJ. Molecular imaging targeting peptide receptors. Methods. 2009:48(2):161-77. doi:10.1016/j.ymeth.2009.03.012.

24. Reubi JC, Schar JC, Waser B, Wenger S, Heppeler A, Schmitt JS, et al. Affinity profiles for human somatostatin receptor subtypes SST1-SST5 of somatostatin radiotracers selected for scintigraphic and radiotherapeutic use. Eur J Nucl Med. 2000;27(3):273-82

25. Fani M, Del Pozzo L, Abiraj K, Mansi R, Tamma ML, Cescato R, et al. PET of somatostatin receptor-positive tumors using 64Cu- and 68Ga-somatostatin antagonists: the chelate makes the difference. J Nucl Med. 2011;52(7):1110-8. doi:10.2967/jnumed.111.087999.

26. Schottelius M, Poethko T, Herz M, Reubi JC, Kessler H, Schwaiger M, et al. First (18)F-labeled tracer suitable for routine clinical imaging of sst receptorexpressing tumors using positron emission tomography. Clin Cancer Res. 2004;10(11):3593-606. doi:10.1158/1078-0432.CCR-03-0359.

27. Sancho V, Di Florio A, Moody TW, Jensen RT. Bombesin receptor-mediated imaging and cytotoxicity: review and current status. Curr Drug Deliv. 2011; 8(1):79-134. doi:10.2174/156720111793663624.

28. Smith CJ, Volkert WA, Hoffman TJ. Gastrin releasing peptide (GRP) receptor targeted radiopharmaceuticals: a concise update. Nucl Med Biol. 2003;30(8): 861-8. doi:10.1016/S0969-8051(03)00116-1.

29. Smith CJ, Volkert WA, Hoffman TJ. Radiolabeled peptide conjugates for targeting of the bombesin receptor superfamily subtypes. Nucl Med Biol. 2005;32(7):733-40. doi:10.1016/j.nucmelbio.2005.05.005.

30. Ray Banerjee S, Pullambhatla M, Foss CA, Falk A, Byun Y, Nimmagadda S, et al. Effect of chelators on the pharmacokinetics of $(99 \mathrm{~m})$ Tc-labeled imaging agents for the prostate-specific membrane antigen (PSMA). J Med Chem. 2013;56(15):6108-21. doi:10.1021/jm400823w.

31. Banerjee SR, Pullambhatla M, Foss CA, Nimmagadda S, Ferdani R, Anderson CJ, et al. (6)(4)Cu-labeled inhibitors of prostate-specific membrane antigen for PET imaging of prostate cancer. J Med Chem. 2014;57(6):2657-69. doi:10.1021/jm401921j.

32. Weineisen $M$, Simecek J, Schottelius $M$, Schwaiger M, Wester HJ. Synthesis and preclinical evaluation of DOTAGA-conjugated PSMA ligands for functional imaging and endoradiotherapy of prostate cancer. EJNMMI Res. 2014;4(63):1-15.

33. Chen $Y$, Pullambhatla M, Foss $C A$, Byun $Y$, Nimmagadda S, Senthamizhchelvan S, et al. 2-(3-\{1-Carboxy-5-[(6-[18F]fluoro-pyridine-3-carbonyl)-amino]-pentyl\}ureido)-pentanedioic acid, [18F]DCFPyL, a PSMA-based PET imaging agent for prostate cancer. Clin Cancer Res. 2011:17(24):7645-53. doi:10.1158/1078-0432. CCR-11-1357.

34. Mease RC, Dusich CL, Foss CA, Ravert HT, Dannals RF, Seidel J, et al. $\mathrm{N}$-[N-[(S)-1,3-Dicarboxypropyl]carbamoyl]-4-[18F]fluorobenzyl-L-cysteine, [18F]DCFBC: a new imaging probe for prostate cancer. Clin Cancer Res. 2008;14(10):3036-43. doi:10.1158/1078-0432.CCR-07-1517.

35. Eder M, Neels $O$, Muller M, Bauder-Wust U, Remde $Y$, Schafer $M$, et al. Novel preclinical and radiopharmaceutical aspects of [68Ga]Ga-PSMA-HBED-CC: a new PET tracer for imaging of prostate cancer. Pharmaceuticals (Basel). 2014;7(7):779-96. doi:10.3390/ph7070779.

36. Eder M, Schafer M, Bauder-Wust U, Hull WE, Wangler C, Mier W, et al. $68 \mathrm{Ga}-\mathrm{complex}$ lipophilicity and the targeting property of a urea-based PSMA inhibitor for PET imaging. Bioconjug Chem. 2012;23(4):688-97. doi:10.1021/bc200279b.

\section{Submit your manuscript to a SpringerOpen ${ }^{\odot}$ journal and benefit from:}

- Convenient online submission

- Rigorous peer review

- Immediate publication on acceptance

- Open access: articles freely available online

- High visibility within the field

- Retaining the copyright to your article

Submit your next manuscript at $>$ springeropen.com 